\title{
Quantity Surveyors' Response to the COVID-19 Outbreak: A Mixed Method Approach
}

\author{
Seng Hansen ${ }^{1,2,}$, Susy F Rostiyanti ${ }^{1,4}$, Rizaldi Rizaldi ${ }^{3}$, Clara Andjarwati ${ }^{4}$ \\ 1 Department of Construction Engineering and Management, Universitas Agung Podomoro, Jakarta, INDONESIA \\ Jalan Letjen S. Parman No.28, Tj. Duren Sel, 11470, Jakarta \\ 2 Department of Construction Management, RMIT University, Melbourne, AUSTRALIA \\ 124 La Trobe St, Melbourne VIC 3000, Australia \\ ${ }^{3}$ Ketua IQSI, Ikatan Quantity Surveyor Indonesia, Jakarta, INDONESIA \\ Jalan Cimandiri No. 6, Cikini, 10330, Jakarta \\ ${ }^{4}$ Bidang Literatur IQSI, Ikatan Quantity Surveyor Indonesia, Jakarta, INDONESIA \\ Jalan Cimandiri No. 6, Cikini, 10330, Jakarta \\ ${ }^{*}$ Corresponding authors: seng.hansen@gmail.com
}

SUBMITTED 19 October 2020 REVISED 11 January 2021 ACCEPTED 23 February 2021

\begin{abstract}
The COVID-19 outbreak began at the end of 2019, and has evolved to a pandemic threatening various industries' sustainability. Decisive actions have been taken to tackle the pandemic's spread, however, various impacts continue to be felt by many industries, including the construction industry. This paper therefore focuses on the COVID-19 outbreak's impact on Quantity Surveyors' (QS) construction projects and activities, as a key profession in the industry. A mixed method approach, questionnaire survey followed by expert interviews, was adopted. Subsequently, 199 valid responses for analysis were obtained from the questionnaire distribution, using descriptive statistics and Significance Index. Furthermore, qualitative data were acquired through semi-structured interviews with five experts, and analyzed using a structured thematic analysis. According to the results, $56.78 \%$ of respondents experienced project slowdowns, $13.57 \%$ experienced project suspensions or terminations, and $12.56 \%$ experienced cost overruns. Most respondents acknowledged the pandemic had present changes to projects (84.92\%), in the form of changes in organization structure, work culture, technological application, and project objectives. Meanwhile, the Significance Index has successfully established an 11-factors ranking, regarding the pandemic's impact on QS activities, with impact on the overall project completion as the most profound impact followed by impacts on project scheduling, supply chain, tendering, cost controlling, and claim management. This study's qualitative and quantitative findings tend to be in accordance, thus, providing some fundamental insights regarding the COVID-19 outbreak's impact on the construction industry, including direct impacts on project sustainability, technology adoption, and project resiliency issues. In addition, this study also contributes to scientific knowledge by discussing the issues and trends of work culture changes in QS professional activities.
\end{abstract}

KEYWORDS Construction; COVID-19's impacts; Indonesia; mixed method and quantity surveyors.

(C) The Author(s) 2021. This article is distributed under a Creative Commons Attribution-ShareAlike 4.0 International license.

\section{INTRODUCTION}

The COVID-19 pandemic began at the end of 2019, and has impacted people worldwide, both directly and indirectly, including within the Indonesian construction community. Currently, players in the construction industry are doing everything possible to accommodate these changes and impacts. Various government regulations as well as policies have been issued to prevent the disease's spread, and unfortunately, these also have an impact on the construction business in Indonesia, including supply chain and resource obstruction, quarantine of projects due to positive indications of COVID-19 cases, as well as project delays and terminations.
Meanwhile, not many studies have been conducted regarding the pandemic's potential impacts, solutions and challenges towards the construction industry. Most published studies are more related to COVID-19's impact in the health sector, for instance, publications on coronavirus, immune response, respiratory problems, and health care (Hamidah et al., 2020). The available academic publications related to COVID-19 and the impact on the construction industry include force majeure and changes in law (Hansen, 2020; Yadeta and Pandey, 2020), transportation engineering (Hendrickson and Rilett, 2020), risk communication (Oerther \& Watson, 2020), as well as resilient cities (Chirisa et al., 2020). 
However, in Indonesia, there has been sparse studies on COVID-19's impacts. A bibliometric analysis of COVID-19 research found most of the research publications were conducted by China, followed by the United States, and the United Kingdom (Hamidah et al., 2020). Thus, in Indonesia, only a few studies related pandemic's impact have been conducted (Hansen, 2020; Sarip et al., 2020; Yamali and Putri, 2020), and no studies a focus on QS (quantity surveyors') perspective have been previously conducted. QS plays a crucial role in construction works, especially during a pandemic, and one of the construction industry's professions with experts in construction costs and contracts - COVID19's parameters in the construction industry. Thus, delays due to the pandemic probably impacted QS activities in terms of decreased productivity and performances, delays in progress payments and disruptions of the contractual relationship between involved parties. This study therefore aims to investigate the COVID-19 outbreak's impact on the sustainability of construction projects and QS activities, in Indonesia.

\section{LITERATURE REVIEW}

The COVID-19 outbreak has become a global disruption with economic, environmental and social impacts (Hendrickson and Rilett, 2020). Several studies and efforts have been made to mitigate the pandemic's impact, especially in the health sector (Hamidah et al., 2020). The construction industry was also affected by the COVID-19 outbreak and policies have been implemented by the government to overcome the disease's spread. However, not much research has been carried out regarding COVID19's impact on the construction industry, especially in Indonesia.

Furthermore, only a few available literatures provide insight into pandemic's impact on the construction industry. Ballard (2020), in Hendrickson and Rilett (2020) argued roadways and rail transportation have furthered the disease's spread across cities and countries. Assessments about COVID-19's impact on the construction industry have been conducted in
Australia (MasterBuilders, 2020), Ethiopia (Gashahun, 2020), India (KPMG, 2020), Malaysia (Gamil and Alhagar, 2020), Maldives (MNU, 2020) and Oman (Al Amri and Marey-Perez, 2020). Yadeta and Pandey (2020) analyzed the pandemic's global impact on the construction industry with two proposed scenarios, force majeure and changes in law. Similarly, Hansen (2020) studied the pandemic's impact on construction contracts and reported on whether the outbreak constituted a force majeure in Indonesia.

In anticipation of COVID-19's negative effects, governments have implemented several measures to curb the pandemic's spread, including full or partial lockdowns, border closures, domestic health protocols, and limiting the public transportation system (Choudhury et al., 2020; Hansen, 2020). In Indonesia, the government has issued various regulations for handling COVID-19 outbreaks in construction projects. The construction industry is one of eleven business sectors with the privilege to during a period of large-scale social restriction (DKI Governor's Regulation No. 33 of 2020), however, various measures and standard health protocols must be met.

These measures to the COVID-19's spread on construction sites include issuing a COVID-19 prevention protocol in construction services sector through a Ministerial Instruction No. 02/IN/M/2020. This instruction provides a mechanism of the outbreak's prevention on construction sites, and includes four stages, establishing a prevention task force, on site outbreak identification, health facilities provision and disease prevention. Thus, both employers and contractors are responsible for preventing COVID-19 spread, on construction project sites.

\section{METHODS}

This study adopts a mixed method approach, where the authors gather QS professionals' opinions regarding COVID-19's impacts towards activities, provide a validation of the gathered opinions through expert interviews, and 
highlight fundamental insights from the findings. This method involves two data collection techniques, questionnaire survey and

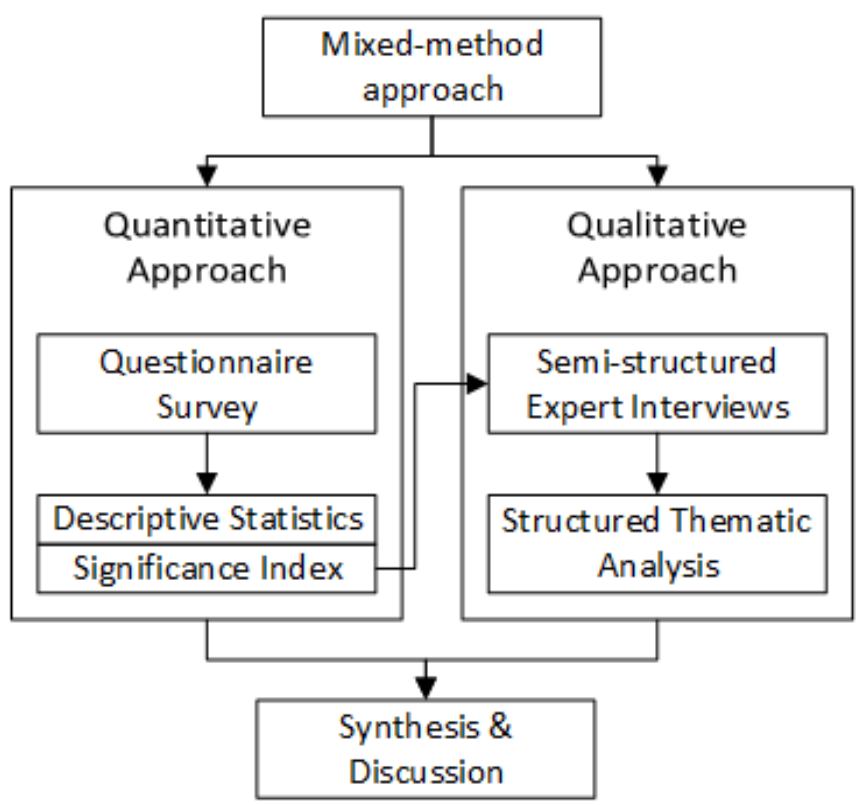

Figure 1. Research methodology.

An online questionnaire survey was distributed to QS professionals in a one-month period (from 28 August - 27 September, 2020) through Google Forms. The questionnaire comprised two parts, the respondent's profile and the QS response survey, where a five-point Likert scale was used with ' 1 ' representing the lowest implications and semi-structured expert interviews. Figure 1 illustrates the methodology adopted in this study.

' 5 ' representing the highest implications. Subsequently, the data obtained was analyzed using descriptive statistics and Significance Index $(S i)$. The statistical analysis comprises mean, measuring the numbers' average, and Standard Deviation $(S D)$, measuring the amount of variation for a given value set. Meanwhile, Si has been widely adopted for risk significance and factors ranking calculation (Zhang, 2006; Ke et al., 2009; Hansen and Rostiyanti, 2019). The formula below was used to analyze 11 items, using $S i$.

$S_{i}=\frac{R_{i 1} \times 20+R_{i 2} \times 40+R_{i 3} \times 60+R_{i 4} \times 80+R_{i 5} \times 100}{R_{i 1}+R_{i 2}+R_{i 3}+R_{i 4}+R_{i 5}}$

Where, $S i$ denotes the significance index for factor $-i ; \mathrm{R}_{\mathrm{i} 1}, \mathrm{R}_{\mathrm{i} 2}, \mathrm{R}_{\mathrm{i} 3}, \mathrm{R}_{\mathrm{i} 4}$, and $\mathrm{R}_{\mathrm{i} 5}$ represent numbers of respondents' responses to each scale (1 to 5) for factor-I, respectively.

Only 199 of the 206 responses collected were valid for analysis. Table 1 shows the surveyed respondent profiles, based on responses received. In providing responses, the respondents' were asked to make an assessment based on the last project worked on (project profiles). 
Table 1. Surveyed respondent and project profiles.

\begin{tabular}{|c|c|c|c|c|c|}
\hline Respondent profiles & Number & $\%$ & Project profiles & Number & $\%$ \\
\hline Educational background & & & Project type & & \\
\hline High School & 6 & $3.02 \%$ & Airports & 3 & $1.51 \%$ \\
\hline 3-year Diploma & 17 & $8.54 \%$ & Roads & 44 & $22.11 \%$ \\
\hline Bachelor degree & 140 & $70.35 \%$ & Buildings & 127 & $63.82 \%$ \\
\hline Master degree & 32 & $16.08 \%$ & Factories and plants & 4 & $2.01 \%$ \\
\hline Doctoral degree & 3 & $1.51 \%$ & Water infrastructure & 3 & $1.51 \%$ \\
\hline Others & 1 & $0.50 \%$ & Mining & 8 & $4.02 \%$ \\
\hline Total & 199 & $100 \%$ & Others & 10 & $5.03 \%$ \\
\hline Working experience & & & Total & 199 & $100 \%$ \\
\hline Less than 5 years & 25 & $12.56 \%$ & Project value (in IDR) & & \\
\hline $5-10$ years & 78 & $39.20 \%$ & Less than 1 Billion & 16 & $8.04 \%$ \\
\hline $10-15$ years & 45 & $22.61 \%$ & 1-10 Billion & 34 & $17.09 \%$ \\
\hline More than 15 years & 51 & $25.63 \%$ & 10-100 Billion & 57 & $28.64 \%$ \\
\hline Total & 199 & $100 \%$ & More than 100 Billion & 92 & $46.23 \%$ \\
\hline Affiliation & & & Total & 199 & $100 \%$ \\
\hline Contractor & 60 & $30.15 \%$ & Duration & & \\
\hline Consultant & 99 & $49.75 \%$ & Less than 1 year & 46 & $23.12 \%$ \\
\hline Owner & 25 & $12.56 \%$ & 1-2 years & 84 & $42.21 \%$ \\
\hline Government & 9 & $4.52 \%$ & More than 2 years & 69 & $34.67 \%$ \\
\hline Others & 6 & $3.02 \%$ & Total & 199 & $100 \%$ \\
\hline Total & 199 & $100 \%$ & & & \\
\hline \multicolumn{6}{|l|}{ IQSI Member } \\
\hline Yes & 104 & $52.26 \%$ & & & \\
\hline No & 95 & $47.74 \%$ & & & \\
\hline Total & 199 & $100 \%$ & & & \\
\hline
\end{tabular}

The quantitative analysis' findings were used to develop interview questions. Subsequently, a total of five interviews were conducted with experts meeting the criteria of being QS professionals with over twenty years of work experience, a job position as a manager or above, and a representative of the construction industry's three main stakeholders, contractors, consultants and employers. Actual interviews were conducted within nine days, with an average interview duration and total expert experience of 31'09" and 138 years, respectively.
In this study, the respondent participations were voluntary, and all interviews were recorded. A structured thematic analysis was also conducted to analyze the interview data. Subsequently, all findings were discussed and presented in this paper, while withholding the any respondent's personal information (non-identifiable data) not directly related to the research topic. Table 2 presents the interviewed expert profile. 
Table 2. Interviewed expert profiles.

\begin{tabular}{lllcc}
\hline Expert & Working experience & Current affiliation & Current position & Interview duration \\
\hline E1 & 30 years & QS Consultant & Country Director & $33^{\prime} 08^{\prime \prime}$ \\
E2 & 20 years & Contractor & Commercial \& Contract Manager & $27^{\prime} 49^{\prime \prime}$ \\
E3 & 20 years & Owner & Project Director & $30^{\prime} 40^{\prime \prime}$ \\
E4 & 37 years & QS Consultant & Company Owner & $24^{\prime} 23^{\prime}$ \\
E5 & 31 years & QS Consultant & President Director & $39^{\prime} 46^{\prime}$ \\
\hline
\end{tabular}

\section{RESULTS}

\subsection{Quantitative Findings}

Figures 2 and 3 show the descriptive statistical analysis results, where $56.78 \%$ of the projects experienced a slowdown in work implementation, possibly leading to a time extension. In addition, the impact of project suspensions or terminations and cost overruns contributed $13.57 \%$ and $12.56 \%$ respectively. Meanwhile, $17.09 \%$ of projects were admittedly not affected by the COVID-19 outbreak.



$$
\begin{aligned}
& \text { - Impacted (cost overruns) } \\
& \text { - Impacted (suspensions or terminations) } \\
& \text { - Impacted (slowdown) } \\
& \text { - Not impacted }
\end{aligned}
$$

Figure 2. Project status.

Furthermore, most respondents acknowledged the pandemic had present changes to projects $(84.92 \%)$, in the form of changes in organizational structure, work culture, technological application, as well as project targets and objectives. Conversely, $11.56 \%$ of respondents stated no significant changes occurred, while $3.53 \%$ did not provide a clear answer.

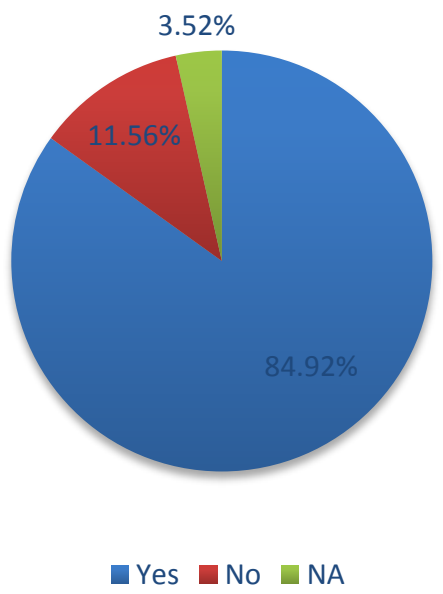

Figure 3. Change response due to COVID-19.

Table 3 shows the pandemic's impact on various QS professional activities, analyzed using the Significance Index method. According to the table, the pandemic has a profound impact on the overall project completion (81.71), followed by impacts on project scheduling (79.40) and supply chain (76.68), and other QS activities, including tendering (75.48), overall project cost controlling (73.27), as well as claim and dispute management (72.16). Meanwhile, activities related to project quality were least impacted according to respondents, with a 59.80 value. 
Table 3. QS responses to COVID-19's impact.

\begin{tabular}{clcccc}
\hline No & \multicolumn{1}{c}{ Pandemic Impact Response } & Mean & $S D$ & $S i$ & Rank \\
\hline 1 & on the overall project schedule & 4.09 & 0.97 & 81.71 & 1 \\
2 & on project scheduling activities & 3.97 & 0.96 & 79.40 & 2 \\
3 & on project supply chain activities & 3.83 & 1.03 & 76.68 & 3 \\
4 & on project tendering activities & 3.77 & 1.01 & 75.48 & 4 \\
5 & on the overall project costs & 3.66 & 1.08 & 73.27 & 5 \\
6 & on claim management and dispute resolution activities & 3.61 & 1.00 & 72.16 & 6 \\
7 & on valuation activities & 3.61 & 1.04 & 72.16 & 7 \\
8 & on contract administration and management activities & 3.60 & 1.02 & 72.06 & 8 \\
9 & on cost estimating activities & 3.58 & 1.06 & 71.66 & 9 \\
10 & on project team readiness and resilient & 3.28 & 0.99 & 65.53 & 10 \\
11 & on the overall project quality & 2.99 & 1.26 & 59.80 & 11 \\
\hline
\end{tabular}

\subsection{Qualitative Findings}

The results of the quantitative analysis above were used as a basis for developing interview questions. Subsequently, the collected interview data were analyzed in a structured manner, based on the discussion's themes. Table 4 shows the five experts' key responses, thus, enabling an easier understanding of this interview's findings. 
Table 4. Expert interview key responses

\begin{tabular}{|c|c|}
\hline Questions & Key Responses \\
\hline \multicolumn{2}{|c|}{ Impacts of COVID-19 to construction projects } \\
\hline $\begin{array}{l}\text { What are the } \\
\text { impacts of COVID- } \\
19 \text { to construction } \\
\text { projects? }\end{array}$ & $\begin{array}{l}\text { - While there are project slowdowns, on-going projects continue to work (E1, E4, E5) } \\
\text { - Most new projects or projects in tendering process are being held (E1, E4) } \\
\text { - Decrease in productivity (E2) } \\
\text { - Early pandemic period in Indonesia (Mar-May'20) is the toughest (E3) }\end{array}$ \\
\hline $\begin{array}{l}\text { How does your } \\
\text { company respond } \\
\text { to the impact of } \\
\text { COVID-19? }\end{array}$ & $\begin{array}{l}\text { - Targets and goals adjustment (E1) } \\
\text { - Negotiation between parties involved (E1) } \\
\text { - Mapping all potential problems to anticipate early (E2) } \\
\text { - Develops different scenarios to predict the impact of COVID-19 (E3) } \\
\text { - Compliances with health protocols including work from home/remote working, work } \\
\text { - } \text { shift, and physical distancing (E1, E2, E3, E4, E5) } \\
\text { - Make use of digitalization technology (E1, E2, E4, E5) }\end{array}$ \\
\hline $\begin{array}{l}\text { How does your } \\
\text { company respond } \\
\text { to the possibility of } \\
\text { extension of time } \\
\text { claim? }\end{array}$ & $\begin{array}{l}\text { - This is a neutral event to be negotiated between parties (E3, E4) } \\
\text { - Requires proof regarding the impact of COVID-19 on project delays (E2) } \\
\text { - Contractors must exercise notification procedure to inform owners regarding the } \\
\text { potential impacts of COVID-19 (E5) }\end{array}$ \\
\hline $\begin{array}{l}\text { How does your } \\
\text { company respond } \\
\text { to the possibility of } \\
\text { additional costs } \\
\text { claim? }\end{array}$ & $\begin{array}{l}\text { - This tends to increase the preliminary costs (E1, E4) } \\
\text { - This is a neutral risk to be shared and discussed between parties involved (E3, E5) } \\
\text { - Requires proof regarding the impact of COVID-19 on project costs (E2) }\end{array}$ \\
\hline $\begin{array}{l}\text { What other issues } \\
\text { have occurred as } \\
\text { the result of } \\
\text { COVID-19? }\end{array}$ & $\begin{array}{l}\text { - Requires adjustments to changes in work culture (E2) } \\
\text { - Some activities currently have to be performed on-site (E4) } \\
\text { - Commercial issues, for instance, shifting spending priorities, payment delays, and } \\
\text { discounts (E3) }\end{array}$ \\
\hline \multicolumn{2}{|c|}{ Impacts of COVID-19 to QS activities and profession } \\
\hline $\begin{array}{l}\text { What are the } \\
\text { impacts of COVID- } \\
19 \text { on QS activities? }\end{array}$ & $\begin{array}{l}\text { - Utilizes e-tendering system or online tendering (E1, E4, E5) } \\
\text { - Utilizes technology to inspect project progress such as video inspection (E5) } \\
\text { - Combination of remote working and on-site working (E1) } \\
\text { - Changing work culture from process-oriented to output-oriented (E5) }\end{array}$ \\
\hline $\begin{array}{l}\text { What are the } \\
\text { difficulties of } \\
\text { remote working? }\end{array}$ & $\begin{array}{l}\text { - Connection problem (E1) } \\
\text { - Inadequate supporting infrastructure (E3) } \\
\text { - Constraints related to habits and adaptation to new things (E3) } \\
\text { - Coordination and monitoring problems (E5) }\end{array}$ \\
\hline $\begin{array}{l}\text { How do you see the } \\
\text { trend going } \\
\text { forward? }\end{array}$ & $\begin{array}{l}\text { - Difficulties in QS job opportunities due to current economic conditions (E2, E4) } \\
\text { - Work culture changes (E1, E3, E4, E5) } \\
\text { - Efficiency efforts to increase company's and project's resilience have been carried out } \\
\text { (E2, E4) }\end{array}$ \\
\hline
\end{tabular}

\section{DISCUSSION}

The quantitative and qualitative analyses above provide several fundamental insights regarding the pandemic's impact on construction projects and QS professional activities, in Indonesia. From this study, most of these projects (82.91\%) were affected by the COVID-19 outbreak. These impacts range from project slowdowns, cost overruns, to project suspensions or even terminations. Meanwhile, in other countries, similar situations were also experienced. In Oman, project slowdowns occurred due to a decrease in workers, and this reached $7.38 \%$ between January and May, 2020 (Al Amri and Marey-Perez, 2020), while in Malaysia, the disease's outbreak led to complete suspension of most construction, with only a few essential projects currently running, for instance, medical facilities expansion to cope with the high 
demand for treatment spaces (Gamil and Alhagar, 2020). Projects experiencing a slowdown due to COVID-19 are most likely to apply for time extension (Hansen, 2020). However, with regard to claims for additional costs due to the pandemic, the involved parties, the owner, contractor and QS consultant, require negotiation and impact proving.

Conversely, suspension and termination decisions were initiated by the owner and mutually agreed upon by all parties. Generally, projects requiring suspension or termination often recently began on-site work. Meanwhile, several projects are not affected by the pandemic, due to various reasons, including projects nearing completion during the pandemic's start, with a loose time schedule enabling sufficient float to anticipate the disease's impact with regard to time aspect; or located in an area unaffected by the pandemic or by large-scale social restrictions (PSBB) as well as lockdowns. Similarly, KPMG (2020) distinguished the COVID-19's impact across the project life cycle from construction near completion experiencing minimal impact, projects under execution being negatively affected by the lockdown, projects in development stage, with secured land and about to commence execution have to be re-estimated from both cost and time perspectives, and projects in conceptual stage require reevaluation, based on priority.

In terms of changes, most projects (84.92\%) admit that COVID-19 outbreak has led to changes in construction projects including project targets adjustment, organizational structure as well as work culture changes, and these currently emphasize more on the construction workers' health aspects. Hansen (2020) reported compliances with health protocols were dominantly felt with the formation of COVID-19 prevention and control teams in each construction project, while Gashahun (2020) argued social distancing, and provision of PPEs as well as sanitizer, alternative arrangements for transportation, facilities, working hours for staff and labor are possible mechanisms to minimize COVID-19's impact on project sites. In addition, the use of QS-related digital technology is increasingly being promoted, to support the physical distancing program and consequently, prevent the disease's spread among QS professionals.

In Indonesia, the construction industry is one of eleven essential business sectors allowed to continue operations during the large-scale social restrictions (DKI Governor's Regulation No. 33 of 2020). However, QS companies in the industry continue to carry out efficiency efforts to build resilience, amid this pandemic. This is possible by reducing non-priority programs, including new QS employee recruitments, utilizing QSrelated technology to enable continual competition, and changing the paradigm from a process-oriented to a results-oriented culture. Therefore, the use of technology must be accompanied by availability of adequate infrastructure and willingness on the part of QS professionals. Considering the large number of remotely conductible QS activities, the orientation of activities ha also changed because supervision of remote work is not possible. Thus, remote working requires a change in work culture to result-orientation, where a QS professional's performance is measured based on work results.

\section{CONCLUSION}

The current COVID-19 pandemic has impacted the construction industry, both directly and indirectly. Therefore, the industry must be vigilant and alert in dealing with changes due to countermeasures implemented by the Indonesian government. As one of this industry's important professions, QS plays a crucial role in supporting resilience efforts carried out by key stakeholders. Meanwhile, QS professionals must also be able to continue to adapt by developing competencies, in the midst of these uncertain situations.

This study has successfully examined the COVID-19 outbreak's impact on the Indonesian construction industry, ranging from project slowdowns, cost overruns, to project suspensions 
and even terminations. Furthermore, the outbreak has also presented several changes in the industry. Thus, change management becomes crucial during this uncertain time and probably include project targets adjustment, organizational structure and work culture changes on project sites. From the QS perspective, the disease's outbreak has led to several impacts on professional activities, including contractual arrangement regarding project time completion and suspension, project cost control, claim arrangement and negotiations, as well as project tendering.

Thus, this paper contributes by reviewing the pandemic's impact on the construction industry and QS professional activities, in Indonesia. In addition, this study has provided an empirical data to understand the current phenomena and discuss the various impacts on project adjustments as well as QS activities. This paper is also useful for providing a basis for further research, including potential time extensions and additional costs claims, as well as work culture changes in the construction industry due to the COVID-19 outbreak, considering previous research related the outbreak's impacts with regard to the construction industry, are currently sparse.

\section{DISCLAIMER}

The authors declare no conflict of interest.

\section{AVAILABILITY OF DATA AND MATERIALS}

All data are available from the corresponding author.

\section{ACKNOWLEDGMENTS}

The authors are grateful to Universitas Agung Podomoro, Ikatan Quantity Surveyor Indonesia (IQSI), and all respondents involved in this study.

\section{REFERENCES}

Al Amri, T. \& Marey-Perez, M., 2020. Impact of Covid-19 on Oman's Construction Industry. Technium Social Sciences Journal, 9, pp. 661-670.
Chirisa, I., Mutambisi, T., Chivenge, M., Matamanda, A. R. \& Ncube, R., 2020. Disaster Mitigation and Response in Cities: Drawing Lessons from COVID-19 Pandemic. Journal of Social Sciences, 63(1-3), pp. 21-31.

Choudhury, P. R., Ghosh, R. K. \& Sindhi, S., 2020. Covid-19 crisis, pandemic resilience and linkages to land: An exposition. IIMA Working Paper WP 2020-05-01. Available at https://dx.doi.org/10.2139/ssrn.3625042.

DKI Governor's Regulation No. 33 of 2020 concerning The Implementation of Large-Scale Social Restriction in the Handling of Corona Virus Disease 2019 (COVID-19) in the Jakarta Capital City Province.

Gamil, Y. \& Alhagar, A., 2020. The Impact of Pandemic Crisis on the Survival of Construction Industry: A Case of COVID-19. Mediterranean Journal of Social Sciences, 11(4), pp. 122-128.

Gashahun, A. D., 2020. Assessment on Impact of Covid-19 on Ethiopian Construction Industry. International Journal of Engineering Science and Computing, 10(7), pp. 26889-26894.

Hamidah, I., Sriyono \& Hudha, M. N., 2020. A Bibliometric Analysis of Covid-19 Research using VOSviewer. Indonesian Journal of Science \& Technology, 5(2), pp. 209-216.

Hansen, S., 2020. Does the COVID-19 Outbreak Constitute a Force Majeure Event? A Pandemic Impact on Construction Contracts. Journal of the Civil Engineering Forum, 6(2), pp. 201-214.

Hansen, S. \& Rostiyanti, S. F., 2019. Indonesian Contractor Professionals' Perception on Problems in Construction Claim Management. Malaysian Construction Research Journal, 27(1), pp. 69-78.

Hendrickson, C. \& Rilett, L. R., 2020. The COVID-19 Pandemic and Transportation Engineering. Journal of Transportation Engineering, Part A: Systems, 146(7), pp. 01820001. 
Instruction of the Ministry of Public Works and Housing No. 02/IN/M/2020 concerning Protocol for Preventing the Spread of Corona Virus Disease 2019 (COVID-19) in the Construction Services.

Ke, Y., Wang, S. Q., Chan, A. P. C. \& Cheung, E., 2009. Research Trend of Public-Private Partnership in Construction Journals. Journal of Construction Engineering and Management, 135(10), pp. 1076-1086.

KPMG, 2020. COVID-19: Assessment of economic impact on construction sector in India. Company report [Online] Available at: https://assets.kpmg/content/dam/kpmg/in/pdf/2 020/05/covid-19-assessment-economic-impactconstruction-sector.pdf [Accessed on 10 January 2021].

MasterBuilders, 2020. Impact of Covid-19 on the Building \& Construction Industry. [Online] Available at: https://www.masterbuilders.com.au/getmedia/e0 06e78e-8c02-48b2-8d5b-7ae9519ea7c6/Impactof-COVID-19-Survey.pdf [Accessed on 10 January 2021].

MNU (Maldives National University), 2020. The Impact of COVID-19 on the Construction Sector of the Maldives. Academic report [Online] Available at: $\quad$ https://mnu.edu.mv/wpcontent/uploads/2016/10/THE-IMPACT-OF-
COVID-19-ON-THE-CONSTRUCTION-

SECTOR.pdf [Accessed on 10 January 2021].

Oerther, D. B. \& Watson, R., 2020. Risk Communication is Important for Environmental Engineering during COVID-19. Journal of Environmental Engineering, 146(10), pp. 01820002.

Sarip, Syarifudin, A. \& Muaz, A., 2020. Dampak COVID-19 Terhadap Perekonomian Masyarakat dan Pembangunan Desa. Al-Mustashfa: Jurnal Penelitian Hukum Ekonomi Islam, 5(1), pp. 10-20.

Yadeta, A. E. \& Pandey, D., 2020. Analysis of the Global Impact of the Pandemic (COVID-19) on Construction Industry: Possible Scenarios. Current Trends in Civil \& Structural Engineering, 6(4), pp. 1-8.

Yamali, F. R. \& Putri, R. N., 2020. Dampak Covid-19 Terhadap Ekonomi Indonesia. Ekonomis: Journal of Economics and Business, 4(3), pp. 384-388.

Zhang, X., 2006. Public Clients' Best Value Perspectives of Public Private Partnerships in Infrastructure Development. Journal of Construction Engineering and Management, 132(2), pp. 107-114. 